\title{
PENGOLAHAN LIMBAH CAIR RUMAH SAKIT SECARA SONOCHEMICAL
}

\section{The Treatment of Hospital Wastewater by Sonochemical Method}

\author{
Laila Kusuma*, Darmadi, dan Adisalamun \\ Jurusan Magister Teknik Kimia, Fakultas Teknik, Universitas Syiah Kuala \\ Jln. Tgk. Syech Abdurrauf 7 Darussalam Banda Aceh 23111, Indonesia \\ *e-mail: Ikusuma62@gmail.com
}

Diterima: 17 Maret 2017, revisi akhir: 14 Juni 2017 dan disetujui untuk diterbitkan: 16 Juni 2017

\begin{abstract}
ABSTRAK
Rumah sakit sebagai penyedia layanan jasa memegang peranan cukup penting dalam kehidupan manusia, terutama bagi orang-orang yang sedang mengalami gangguan fisik dan mental. Berbagai jenis penyakit dan terapi yang dilakukan di rumah sakit telah menjadikannya sebagai salah satu penghasil limbah berbahaya dan infeksius yang memerlukan penanganan dan pengolahan khusus agar tidak mencemari lingkungan yaitu air, tanah dan udara. Pengolahan limbah cair rumah sakit dilakukan untuk mengetahui kemampuan metode sonochemical dalam menurunkan kadar Chemical Oxygen Demand (COD) dan menentukan kondisi optimum dari parameter yang digunakan berdasarkan disain Response Surface Methodology Box-Behnken. Parameter yang mempengaruhi proses ini adalah konsentrasi hidrogen peroksida $\left(\mathrm{H}_{2} \mathrm{O}_{2}\right), \mathrm{pH}$, dan waktu reaksi. Limbah yang digunakan diambil dari instalasi pengolahan air limbah di Rumah Sakit Umum Zainoel Abidin Kota Banda Aceh dengan nilai COD sebesar 260,65 ppm. Kondisi optimum dari proses pengolahan terjadi pada $\mathrm{pH}$ 2, konsentrasi $\mathrm{H}_{2} \mathrm{O}_{2} 500$ ppm, dan waktu reaksi 119,98 menit dengan penurunan COD sebesar $81,88 \%$
\end{abstract}

Kata kunci: Limbah cair rumah sakit, COD, sonochemical, box-behnken, response surface methodology.

\section{ABSTRACT}

Hospital as a service provider has an important role in human life, especially for people who are experiencing physical and mental disorders. Various types of diseases and therapies performed in hospitals has made it as one of the producers of hazardous and infectious waste that requires special handling and processing so as not to pollute the water, soil, and air environment. Hospital wastewater treatment was conducted to determine the ability of sonochemical method to reduce level of Chemical Oxygen Demand (COD) and determine the optimum conditions of the parameters used by the design of Response Surface Methodology Box-Behnken. The parameters that affected this process was the concentration of hydrogen peroxide $\left(\mathrm{H}_{2} \mathrm{O}_{2}\right), \mathrm{pH}$, and reaction time. The Waste used was taken from the waste water treatment plant in Zainoel Abidin General Hospital in Banda Aceh with COD value $260.65 \mathrm{ppm}$. The optimum conditions of this treatment process occured at $\mathrm{pH} 2, \mathrm{H}_{2} \mathrm{O}_{2}$ concentration $500 \mathrm{ppm}$, and reaction time 119.98 minutes with reduction of COD was $81.88 \%$.

Keywords: Hospital wastewater, COD, sonochemichal, box-behnken, response surface methodology

\section{PENDAHULUAN}

Pertumbuhan jumlah rumah sakit meningkat dari tahun ke tahun seiring meningkatnya kebutuhan masyarakat terhadap pelayanan kesehatan. Oleh karena itu, limbah yang dihasilkan dari kegiatan rumah sakit juga akan meningkat, begitu juga dengan dampak yang ditimbulkan karena limbah rumah sakit termasuk ke dalam jenis limbah infeksius atau limbah B3 (Bahan Beracun dan 
Berbahaya). Pemerintah telah menetapkan peraturan-peraturan terkait hal tersebut yaitu Peraturan Menteri Lingkungan Hidup Republik Indonesia No. 5 Tahun 2014 tentang Baku Mutu Air Limbah dan Permenkes 1204/Menkes/PerXI/2004, tentang Persyaratan Kesehatan Lingkungan Rumah Sakit serta Peraturan Pemerintah Nomor 18 Tahun 1999 dan PP No. 85 Tahun 1999, tentang Pengelolaan Limbah Bahan Berbahaya dan Beracun.

Rumah sakit di Provinsi Aceh telah memiliki Instalasi Pengolahan Air Limbah (IPAL), namun sebagian besar tidak berfungsi dengan baik atau belum memenuhi standar. Pengelolaan limbah cair rumah sakit memerlukan penanganan yang serius agar hasil yang diperoleh ramah lingkungan.

Pengolahan limbah cair rumah sakit umumnya dilakukan dengan proses biologis yaitu proses aerob dan an-aerob. Penguraian limbah memerlukan waktu minimal 30 hari dengan tingkat efisiensi sangat tergantung pada kemampuan bakteri pengurainya. Persyaratan minimal yang harus dipenuhi dengan metode ini adalah tersedianya kolam buatan pengolahan limbah cair. Sistem harus terdiri dari dua kolam yang saling berhubungan untuk mendapatkan derajat purifikasi limbah cair sesuai dengan standar WHO. Kendala yang sering dihadapi adalah pendangkalan kolam yang mengakibatkan efektivitas mikroba berkurang (WHO, 2005).

Berbagai teknologi telah diterapkan untuk mengatasi permasalahan tersebut, salah satunya adalah Advanced Oxidation Process (AOP). Teknologi AOP tersebut berkembang sangat pesat yang ditandai dengan diselenggarakannya konferensi internasional yaitu The Third European Conference on Environmental Applications of Advanced Oxidation Process (EAAOP-3) pada tanggal 28-30 Oktober 2013 di Almeira, Spanyol. Konferensi tersebut diselenggarakan untuk menunjukkan temuan-temuan terbaru teknologi AOP dalam proses remediasi air permukaan, air minum, air tanah, air perkotaan, limbah industri dan agroindustri, kontaminasi udara dan tanah (Mantzavinos et al., 2014).
Menurut (Mahamuni and Adewuyi, 2010), kombinasi teknologi AOP dengan radiasi ultrasonik, merupakan suatu metode yang digemari untuk pengolahan limbah cair. Pada proses ini akan dihasilkan senyawa radikal $\mathrm{OH}^{*}$ dalam larutan air dan dengan adanya ultrasonik zat-zat pencemar akan teroksidasi. Proses tersebut dikenal dengan istilah sonochemical, yaitu suatu proses yang mempelajari pengaruh gelombang ultrasonik terhadap reaktannya. Pada proses sonochemical, frekuensi ulltrasonik yang digunakan adalah $20 \mathrm{kHz}-1 \mathrm{mHz}$ (Mahamuni and Adewuyi, 2010) (Neppolian et al., 2012). Pada proses sonochemical penggunaan gelombang ultrasonik biasanya dikombinasikan dengan $\mathrm{O}_{3}$ atau $\mathrm{H}_{2} \mathrm{O}_{2}$.

Menurut (Qiu et al., 2014), pada proses penggabungan ultrasonik dengan hidrogen peroksida (US/ $\mathrm{H}_{2} \mathrm{O}_{2}$ ) akan menghasilkan suatu radikal $\mathrm{OH}^{*}$ disaat terjadi pirolisis $\mathrm{H}_{2} \mathrm{O}_{2}$ melalui fenomena kavitasi. Kavitasi akan terjadi di saat iradiasi ultrasonik dalam media cairan. Menurut (Patil et al., 2014), kavitasi merupakan suatu proses pembentukan, pertumbuhan dan diikuti dengan penghancuran rongga yang melepaskan energi lokal dengan membangkitkan hot spot dan radikal bebas yang sangat reaktif. Molekul-molekul air akan mengalami proses disosiasi termal dan menghasilkan radikal hidroksil dan radikal atom hidrogen yang ditunjukkan pada persamaan (1) (Garcia et al., 2010).

$\mathrm{H}_{2} \mathrm{O}_{(\mathrm{g})} \longrightarrow \mathrm{H}^{*}(\mathrm{~g})+\mathrm{OH}^{*}{ }_{(\mathrm{g})}$

Berdasarkan beberapa literatur di atas, maka AOP khususnya sonochemical merupakan salah satu alternatif yang dapat diterapkan pada pengolahan limbah cair rumah sakit. Penelitian dilakukan berdasarkan disain percobaan Response Surface Methodology (RSM) Box Behnken.

Penelitian bertujuan untuk mengetahui pengaruh variabel $\mathrm{pH}$, hidrogen peroksida, dan waktu reaksi terhadap penurunan kadar COD pada pengolahan limbah cair rumah sakit serta untuk menentukan kondisi optimum dari variabel proses dengan menggunakan RSM Box-Behnken. 


\section{METODOLOGI PENELITIAN}

Bahan yang digunakan sebagai sampel adalah limbah cair yang berasal dari bak sumpit di Instalasi Pengolahan Air Limbah (IPAL) Rumah Sakit Umum Zainoel Abidin Banda Aceh. Hidrogen peroksida $\left(\mathrm{H}_{2} \mathrm{O}_{2} 30 \%\right)$ digunakan sebagai oksidator. Bahan lain yang digunakan adalah aquades, kertas saring, dan bahan kimia analisis COD. Alat yang dibutuhkan adalah pipet volume, beaker glass, gelas ukur, labu ukur, pH meter, termometer, saringan dengan ukuran pori 0,45 $\mu \mathrm{m}$, elenmeyer, corong, timbangan digital, pengaduk magnetik, cawan aluminium, cawan porselen/cawan Gooch, penjepit, kaca arloji, pompa vacuum, reaktor COD, biuret, oven untuk pengoperasian pada suhu $103^{\circ} \mathrm{C}$ sampai dengan $105^{\circ} \mathrm{C}$, desikator yang berisi silika gel, alat ultrasonik dengan frekuensi $47 \mathrm{kHz}$.

\section{Disain Percobaan}

Eksperimen dilakukan berdasarkan disain percobaan RSM Box-Benhken dengan menggunakan software Design Expert Version 6.0.6 guna mendapatkan hasil optimasi persen penurunan COD dan menentukan pengaruh $\mathrm{pH}$, konsentrasi $\mathrm{H}_{2} \mathrm{O}_{2}$ dan waktu reaksi. Disain percobaan RSM Box-Behnken seperti pada Tabel 1.

Tabel 1. Level disain RSM Box-Benhken dengan parameter

\begin{tabular}{lccc}
\hline Variabel & \multicolumn{3}{c}{ Level } \\
\cline { 2 - 4 } & Rendah & Tengah & Tinggi \\
\hline $\mathrm{pH}\left(\mathrm{X}_{1}\right)$ & 2 & 3 & 4 \\
\hline $\begin{array}{l}\text { Konsentrasi } \\
\mathrm{H}_{2} \mathrm{O}_{2}\left(\mathrm{X}_{2}\right)\end{array}$ & 100 & 300 & 500 \\
\hline $\begin{array}{l}\text { Waktu Reaksi } \\
\left(\mathrm{X}_{3}\right)\end{array}$ & 60 & 120 & 180 \\
\hline $\begin{array}{l}\text { Sumber: RSM Box-Behnken } \\
\text { Pada tahap awal dilakukan }\end{array}$
\end{tabular}
karakteristik limbah cair rumah sakit (LCRS) sebelum pengolahan untuk parameter COD (SNI 06-6989.15-2004), $\mathrm{pH}$ (SNI 06-6989.11-2004). Kemudian dilakukan aplikasi sonochemical $\left(\mathrm{US} / \mathrm{H}_{2} \mathrm{O}_{2}\right)$ pada LCRS sebagai berikut:

a. Sampel LCRS dimasukkan ke-17 (tujuh belas) beaker glass ukuran $500 \mathrm{ml}$ masing-masing sebanyak $400 \mathrm{ml}$.

b. $\mathrm{pH}$ sampel LCRS diatur dengan larutan $\mathrm{H}_{2} \mathrm{SO}_{4}$ sesuai dengan variasi variabel penelitian. $\mathrm{pH}$ sampel diukur dengan menggunakan $\mathrm{pH}$ meter Hanna.

c. Larutan $\mathrm{H}_{2} \mathrm{O}_{2}$ ditambahkan sesuai dengan variasi variabel konsentrasi $\mathrm{H}_{2} \mathrm{O}_{2}$ ke dalam 17 (tujuh belas) sampel LCRS masing-masing sebanyak 100 $\mathrm{ml}$. Pada saat penambahan larutan $\mathrm{H}_{2} \mathrm{O}_{2}$ magnetic stirrer telah dihidupkan, dan pengadukan dilakukan pada masing-masing sampel LCRS dengan menggunakan stirrer dan magnetic stirrer selama 60 menit, sampai larutan bercampur homogen, sehingga reaksi di setiap titik diasumsikan sama.

d. LCRS dianalisis karakteristiknya dengan pengujian kadar COD sesuai dengan SNI.

e. Semua sampel yang telah diaplikasikan dengan larutan hidrogen peroksida $\left(\mathrm{H}_{2} \mathrm{O}_{2}\right)$, selanjutnya diolah dengan memberikan getaran dari gelombang ultrasonik (sonochemical). Sonochemical dilakukan dengan menggunakan alat sonicator merk Bransonic dengan frekuensi gelombang $47 \mathrm{kHz}$ sesuai dengan variasi waktu reaksi, kemudian dianalisis karakteristik LCRS yaitu kadar COD sesuai dengan SNI.

\section{HASIL DAN PEMBAHASAN}

\section{Karakterisasi Limbah Cair Rumah Sakit (LCRS)}

Air limbah rumah sakit yang digunakan di dalam penelitian ini diambil dari bak sumpit (bak penampung pertama) yang kemudian diuji karakteristiknya meliputi uji $\mathrm{pH}$ dan COD. Hasil uji karakteristik dari LCRS adalah kadar COD 260,65 ppm dan $\mathrm{pH} 7,3$.

\section{Ringkasan Model Statistik untuk $\%$ Penurunan COD}

Ringkasan Model Statistik memberikan saran untuk pemilihan model yang tepat dan sesuai dengan data eksperimen. Model statistik untuk persentase penurunan COD yang dihasilkan dari disain Box-Behnken ditunjukkan pada Tabel 2. Model ringkasan statistik berfokus pada nilai $R^{2}$ yang diperoleh untuk melihat kesesuaian model. (Manohar et al., 2013), (Qiu et al., 2014), dan (Philippi et al., 2016) 
menyebutkan bahwa nilai $R^{2}$ dapat menunjukkan persamaan model respon yang dievaluasi pada suatu eksperimen. Nilai $R^{2}$ yang diperoleh dari suatu model yang baik adalah lebih besar dari 0,8 karena pada nilai tersebut reaksi yang terjadi dapat dijelaskan dengan baik. $R^{2}$ merupakan nilai yang menjelaskan perbandingan suatu rasio variasi terhadap variasi total dan merupakan ukuran tingkat kesesuaian model. Dari Tabel 2 dapat diketahui bahwa model yang disarankan adalah linier dan kuadratik.
Model kuadratik menunjukkan nilai $\mathrm{R}^{2}$ lebih mendekati 1, yaitu 0,9499 dan $\mathrm{Adj}-R^{2}$ adalah 0,8856 . Pada model linier nilai $R^{2}$ yang diperoleh adalah 0,7542 dan $A d j-R^{2}$ adalah 0,7542 . Oleh karena itu, model yang lebih disarankan adalah quadratik. Pada model quadratik, kemampuan variabel bebas dalam menjelaskan varian dari variabel terikat adalah sebesar 94,99\% (Agarry SE et al., 2012). Selain nilai $R^{2}$, nilai $A d j-R^{2}$ juga merupakan suatu faktor penting untuk melihat kesesuaian regresi model (Qiu et al., 2014).

Tabel 2. Ringkasan Model Statistik untuk \% Penurunan COD.

\begin{tabular}{ccccccc}
\hline \multirow{2}{*}{ Response } & Source & $\begin{array}{l}\text { Std. } \\
\text { Dev }\end{array}$ & R-Square & Adj- $R^{2}$ & Pre- $R^{2}$ & PRESS \\
\hline \multirow{3}{*}{$\begin{array}{c}\text { Persen penurunan } \\
\text { COD }\end{array}$} & Linear & 5,32 & 0,8003 & 0,7542 & 0,6369 & $\begin{array}{c}669,98 \\
\text { (disarankan) }\end{array}$ \\
\cline { 2 - 7 } & $2 F I$ & 5,34 & 0,8454 & 0,7527 & 0,4340 & 1044,24 \\
\cline { 2 - 6 } & Quadratic & 3,63 & 0,9499 & 0,8856 & 0,2043 & $\begin{array}{c}1468,09 \\
\text { (disarankan) }\end{array}$ \\
\hline
\end{tabular}

Sumber: hasil pengolahan data dari RSM Box-Behnken

Model matematika secara aktual yang diperoleh untuk memprediksi nilai \% penurunan COD pada pengolahan LCRS secara sonochemical adalah seperti persamaan 2 .

$\begin{aligned} Y= & 85.99162-11.99800 X_{1}+0.092768 \\ & X_{2}-0.46653 X_{3}+1.4530\left(X_{1}\right)^{2}+ \\ & 5.81375 E-005\left(X_{2}\right)^{2}+1.64667 E-003 \\ & \left(X_{3}\right)^{2}-0.020387 X_{1} \cdot X_{2}+0.033333 \\ & X_{1} \cdot X_{3}-3.64583 E-005 \quad X_{2} \cdot X_{3}\end{aligned}$

Keterangan:

$\mathrm{X}_{1}=\mathrm{pH}$

$\mathrm{X}_{2}=$ konsentrasi $\mathrm{H}_{2} \mathrm{O}_{2}$

$\mathrm{X}_{3}=$ waktu reaksi

Dari persamaan 2 diketahui bahwa $\mathrm{pH}$ $\left(X_{1}\right)$ dan waktu reaksi $\left(X_{3}\right)$ memiliki pengaruh negatif artinya penambahan kedua variabel tersebut akan mengurangi persentase penurunan COD. Konsentrasi $\mathrm{H}_{2} \mathrm{O}_{2}\left(\mathrm{X}_{3}\right)$ memiliki pengaruh positif artinya penambahan $\mathrm{H}_{2} \mathrm{O}_{2}$ akan meningkatkan persentase penurunan COD. Dari Persamaan 2 diperoleh hasil prediksi dari $\%$ penurunan COD LCRS yang diolah secara sonochemical. Perbandingan data hasil penelitian dengan data hasil dari perhitungan menggunakan persamaan 2 dapat dilihat pada Tabel 3.

Dari Tabel 3 dapat disimpulkan bahwa nilai penurunan COD yang diperoleh dari hasil penelitian dan melalui prediksi model memiliki kesesuaian yang cukup baik. Nilai persentase degradasi COD tertinggi yang diperoleh dari hasil penelitian adalah sebesar $80,16 \%$ dengan konsentrasi $\mathrm{H}_{2} \mathrm{O}_{2}$ 500 ppm, pH 2, dan waktu reaksi selama 120 menit. Nilai persentase degradasi COD yang diperoleh dari prediksi model adalah sebesar $81,88 \%$.

Nilai persentase degradasi COD terendah yang diperoleh dari hasil penelitian adalah sebesar $44,54 \%$ dengan konsentrasi $\mathrm{H}_{2} \mathrm{O}_{2} 100 \mathrm{ppm}, \mathrm{pH}$ 2, dan waktu reaksi selama 120 menit. Pada kondisi yang sama, nilai persentase degradasi COD yang diperoleh dari prediksi model adalah sebesar $48,88 \%$. Berdasarkan data-data tersebut dapat disimpulkan bahwa proses degradasi COD secara sonochemical sangat dipengaruhi oleh $\mathrm{pH}$, konsentrasi $\mathrm{H}_{2} \mathrm{O}_{2}$ serta lamanya waktu reaksi dengan bantuan gelombang ultrasonik.

Untuk kondisi pada titik pusat (center point) dilakukan sebanyak 5 run, yaitu 
pada $\mathrm{pH} 3$, konsentrasi $\mathrm{H}_{2} \mathrm{O}_{2} 300$ ppm, dan waktu reaksi 120 menit. Nilai persentase degradasi COD yang diperoleh dari hasil penelitian adalah 55,76, 55,86, 56,72,
56,49 dan 56,19\%, sedangkan dari hasil prediksi model adalah $56,20 \%$ untuk ke 5 run tersebut.

Tabel 3. Data hasil eksperimen dan hasil prediksi model terhadap $\%$ penurunan COD

\begin{tabular}{cccccc} 
& \multicolumn{3}{c}{ Nilai level Variabel X } & \multicolumn{2}{c}{ Penurunan COD (\%) } \\
\cline { 2 - 6 } Run & $\mathrm{X}_{1}$ & $\mathrm{X}_{2}$ & $\mathrm{X}_{3}$ & Konsentrasi $\mathrm{H}_{2} \mathrm{O}_{2}$ & Waktu Reaksi \\
& $\mathrm{pH}$ & 300 & 60 & 51,34 & Prediksi \\
\hline 1 & 4 & 500 & 120 & 80,16 & 55,13 \\
2 & 2 & 300 & 120 & 55,76 & 81,88 \\
3 & 3 & 300 & 60 & 72,19 & 69,20 \\
4 & 2 & 300 & 120 & 55,86 & 56,20 \\
5 & 3 & 300 & 120 & 56,72 & 56,20 \\
6 & 3 & 100 & 120 & 44,54 & 48,88 \\
7 & 2 & 500 & 60 & 75,70 & 76,25 \\
8 & 3 & 100 & 60 & 52,60 & 50,53 \\
9 & 3 & 500 & 120 & 67,27 & 62,93 \\
10 & 4 & 300 & 180 & 71,83 & 68,05 \\
11 & 2 & 300 & 120 & 56,49 & 56,20 \\
12 & 3 & 100 & 120 & 47,96 & 46,24 \\
13 & 4 & 500 & 180 & 75,44 & 77,51 \\
14 & 3 & 100 & 180 & 54,09 & 53,54 \\
15 & 3 & 300 & 120 & 56,19 & 56,20 \\
16 & 3 & 300 & 180 & 58,98 & 61,25 \\
17 & 4 & & & & \\
\hline
\end{tabular}

Sumber: Data penelitian sendiri

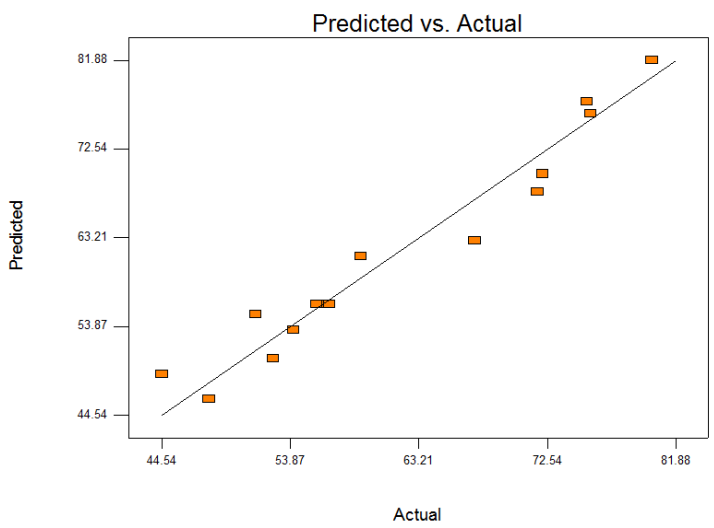

Sumber: Data penelitian sendiri yang diolah

Gambar 1. Hubungan antara nilai hasil penelitian dan nilai prediksi \% penurunan COD pada pengolahan LCRS

Hubungan antara hasil eksperimen dan hasil prediksi pengolahan LCRS terhadap \% penurunan COD, diilustrasikan pada Gambar 1 dan plot normal probabilitas residual penurunan COD pada Gambar 2. Dari gambar tersebut dapat diketahui sejauh mana keakuratan model yang diperoleh, dengan cara membandingkan hasil eksperimen dan hasil prediksi persentase penurunan COD.

Gambar 1 menunjukkan banyaknya titik-titik yang bersinggungan dengan garis diagonal. Hal ini mengindikasikan bahwa nilai eksperimen dan nilai prediksi bersesuaian dengan baik. Plot normal probabilitas antara nilai eksperimen dan nilai prediksi \% penurunan COD juga dapat menunjukkan kesesuaian model kuadrat (Abu et al., 2014).

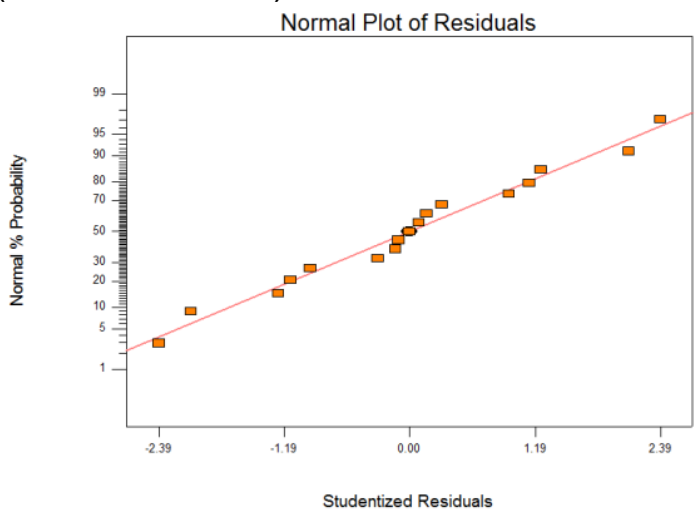

Sumber: Data penelitian sendiri yang diolah

Gambar 2. Plot normal probabilitas residual untuk \% penurunan COD pada pengolahan LCRS 
Gambar 2 menunjukkan plot normal probabilitas residual untuk persen penurunan COD. Normal probabilitas menunjukkan gambaran distribusi suatu nilai residual, yang didefinisikan sebagai perbedaan diantara data prediksi dengan data percobaan yang membentuk suatu garis lurus. Menurut (Qiu et al., 2014), kesesuaian model terhadap asumsi dari ANOVA (Analysis of Variance) dapat ditinjau berdasarkan nilai residual dan internal studentized residual, yang digunakan untuk mengetahui standar deviasi antara hasil eksperimen dengan hasil prediksi model. Gambar 2 tersebut menunjukkan bahwa data eksperimen sangat bersesuaian dengan data prediksi. Hal tersebut ditandai dengan terdistribusinya nilai residual secara normal pada kedua sisi garis lurus.

\section{Analisis Varian (ANOVA) untuk Penurunan COD}

ANOVA adalah suatu teknik pengujian analitikal, digunakan untuk mengevaluasi kesesuaian model persamaan yang diperoleh dari pengolahan data penelitian (Qiu et al., 2014). (Abu et al., 2014) juga mendefinisikan ANOVA sebagai suatu teknik pengujian data secara grafik yang dapat menghasilkan interaksi antara variabel proses dengan variabel respon.

Kualitas kesesuaian model persamaan ditandai dengan tingginya koefisien determinasi $\left(R^{2} \sim 1\right), \quad$ dan kesesuaian statistiknya diperoleh dari Fisher's F-test dan Student's t-test dengan tingkat kepercayaan $95 \%$.

Pada tingkat kepercayaan $95 \%$ hasil dari $F$-test mengindikasikan bahwa semua faktor dan interaksi-interaksi yang terjadi pada disain eksperimen signifikan secara statistik yaitu pada $p<0,05$. Pernyataan tersebut sesuai dengan ANOVA dari hasil pengolahan LCRS secara sonochemical terhadap penurunan COD seperti pada Tabel 4.

Hal pertama yang harus dilakukan untuk analisis output, adalah mendeteksi kesesuaian model. Berdasarkan ANOVA untuk \% penurunan COD pada Tabel 4, dapat disimpulkan bahwa model secara statistik sangat signifikan, yang ditandai dengan $F$-value model 14,76 dan $p$-value 0,0009 . $P$-value lebih kecil dari 0,05 , mengidentifikasikan bahwa model tersebut signifikan.

Model yang signifikan dapat diaplikasikan pada proses pengolahan LCRS secara Sonochemical guna menghasilkan hasil optimum. Nilai $p$-value berfungsi untuk melihat kesesuaian antara setiap koefisien, serta untuk melihat kekuatan interaksi antara masing-masing variabel independen (Liu et al., 2013). Jika nilai Prob > F lebih kecil dari 0,05, maka mengindikasikan model tersebut signifikan, dan untuk nilai Prob > F lebih dari 0,05 mengindikasikan model tersebut tidak signifikan (Qiu et al., 2014).

Tabel 4. ANOVA Hasil pengolahan LCRS secara sonochemical terhadap \% penurunan COD

\begin{tabular}{lcccccc}
\hline Source & Sum of Square & $d f$ & Mean Square & $F$ value & $P$-value Prob $>F$ & Karakteristik \\
\hline Model & 1752,64 & 9 & 194,74 & 14,76 & 0,0009 & Signifikan \\
$\mathrm{A}-\mathrm{pH}$ & 232,96 & 1 & 232,96 & 17,66 & 0,0040 & Signifikan \\
$\mathrm{B}-\mathrm{H}_{2} \mathrm{O}_{2}$ & 1234,55 & 1 & 1234,55 & 93,57 & $<0,0001$ & Signifikan \\
C-t reaksi & 9,05 & 1 & 9,05 & 0,69 & 0,4348 & Tidak signifikan \\
$\mathrm{AB}$ & 66,50 & 1 & 66,50 & 5,04 & 0,0596 & Hampir signifikan \\
$\mathrm{AC}$ & 16 & 1 & 16 & 1,21 & 0,3072 & Tidak signifikan \\
$\mathrm{BC}$ & 0,77 & 1 & 0,77 & 0,058 & 0,8165 & Tidak signifikan \\
$\mathrm{A}^{2}$ & 8,89 & 1 & 8,89 & 0,67 & 0,4388 & Tidak signifikan \\
$\mathrm{B}^{2}$ & 22,77 & 1 & 22,77 & 1,73 & 0,2304 & Tidak signifikan \\
$\mathrm{C}^{2}$ & 147,96 & 1 & 147,96 & 11,21 & 0,0123 & Signifikan \\
\hline
\end{tabular}

Sumber: Data yang diolah

Dari hasil ANOVA pada Tabel 4, tersirat bahwa model signifikan dan dapat diaplikasikan pada proses pengolahan LCRS secara sonochemical guna menghasilkan hasil optimum. Nilai Adeq precision (AP) digunakan untuk mengukur signal dari noise ratio. Nilai AP diharapkan lebih besar dari 4. Pada penelitian ini 
diperoleh nilai AP 12,792 yang mengindikasikan bahwa model dapat menavigasi ruang disain. coeffisient variation (CV) bernilai < 10\% menunjukkan bahwa model signifikan. CV merupakan rasio dari estimasi kesalahan standar terhadap nilai rata-rata dari model eksperimen (Dawood dan Li, 2013). Nilai CV dari pengolahan LCRS untuk parameter COD diperoleh sebesar 5,98\% yang mengindikasikan bahwa model signifikan.

\section{Analisis Response Surface Terhadap Persentase Penurunan COD secara Sonochemical}

Persamaan model yang disarankan oleh software design expert versi 6.0.6 untuk pengolahan LCRS adalah persamaan model kuadratik. Untuk menganalisis model ini dapat digunakan plot tiga dimensi dan plot kontur. Plot tiga dimensi diperoleh dengan cara memplot respon persen degradasi COD LCRS pada sumbu $\mathrm{Y}_{1}$ terhadap sumbu $\mathrm{X}(\mathrm{pH}$, konsentrasi $\mathrm{H}_{2} \mathrm{O}_{2}$, dan waktu reaksi). Setiap plot menujukkan pengaruh dua variabel dalam kisaran yang ditentukan terhadap variabel lain yang dibuat dalam kondisi tetap. Bentuk plot kontur menunjukkan karakteristik dan besarnya pengaruh interaksi antar variabel terhadap respon. Hubungan antara ketiga variabel independen terhadap respon digambarkan pada Gambar 3, 4, dan 5.

Hubungan antara $\mathrm{pH}$ dan konsentrasi $\mathrm{H}_{2} \mathrm{O}_{2}$ terhadap persentase degradasi COD diilustrasikan pada Gambar 3, dimana plot $Y$ adalah persentase degradasi COD dan sumbu $\mathrm{X}$ adalah $\mathrm{pH}$ dan konsentrasi $\mathrm{H}_{2} \mathrm{O}_{2}$ dengan waktu reaksi tetap 120 menit. Dari plot tersebut diperoleh persen penurunan $\mathrm{COD}$ tertinggi pada kondisi $\mathrm{pH}$ terendah dan konsentrasi $\mathrm{H}_{2} \mathrm{O}_{2}$ tertinggi. (Bagal and Gogate, 2014), juga menyebutkan bahwa proses degradasi dengan menggunakan gelombang ultrasonik akan berlangsung lebih baik pada kondisi asam (2-3) daripada kondisi mendekati netral (5-8) dan juga pada kondisi basa (10-12). Pada kondisi asam, reaksi rekombinasi antara radikal bebas akan terhambat sehingga ketersediaan radikal bebas akan meningkat untuk mengoksidasi polutan.
Plot 3D juga menunjukkan bahwa persentase degradasi COD meningkat dengan meningkatnya konsentrasi $\mathrm{H}_{2} \mathrm{O}_{2}$. Kondisi maksimum yang diperoleh dalam penelitian ini adalah pada konsentrasi $\mathrm{H}_{2} \mathrm{O}_{2}$ 500 ppm. Meningkatnya konsentrasi $\mathrm{H}_{2} \mathrm{O}_{2}$ dapat meningkatkan frekuensi tumbukan antar molekul sehingga mempercepat terjadinya reaksi oksidasi.

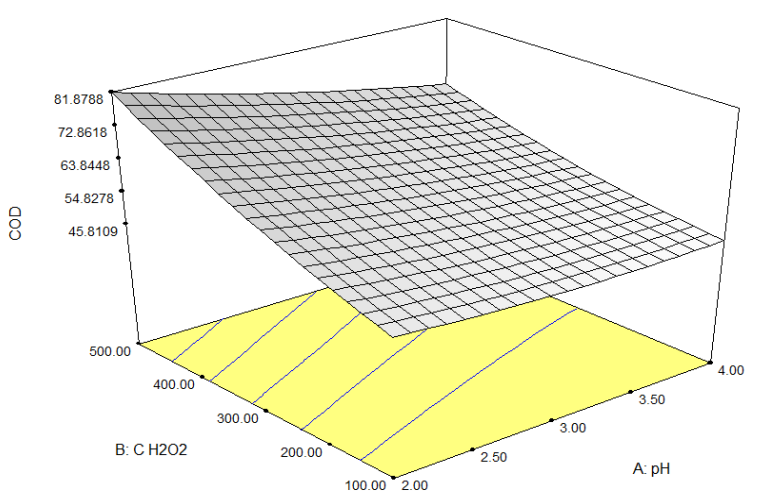

(a)

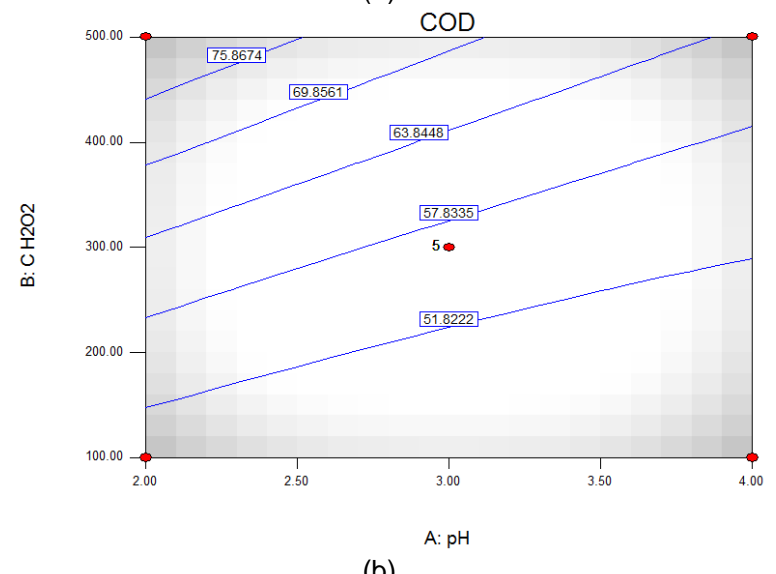

(b)

Sumber: Data yang diolah

Gambar 3. Pengaruh pH dan konsentrasi $\mathrm{H}_{2} \mathrm{O}_{2}$ terhadap \% penurunan COD secara sonochemical: (a) plot 3D (b) plot kontur (waktu reaksi 120 menit)

Reaksi oksidasi yang cepat akan meningkatkan persen penurunan COD dari LCRS. (Mahamuni and Adewuyi, 2010) dan (Petri et al., 2011), menyebutkan bahwa hidrogen peroksida merupakan suatu agen oksidasi kuat dan telah banyak digunakan pada berbagai industri serta pada proses pengolahan air. Ketika bereaksi di air, $\mathrm{H}_{2} \mathrm{O}_{2}$ akan menghasilkan sejumlah besar radikal bebas dan reaktif spesies lainnya yang dapat mengubah dan menguraikan bahan-bahan kimia organik. 
Pada penelitian yang dilakukan oleh (Qiu et al., 2014), disebutkan bahwa proses sonochemical $\left(\mathrm{US} / \mathrm{H}_{2} \mathrm{O}_{2}\right)$ lebih efektif daripada proses pengolahan secara terpisah antara US (gelombang ultrasonik) dan $\mathrm{H}_{2} \mathrm{O}_{2}$. Hal tersebut terjadi karena $\mathrm{H}_{2} \mathrm{O}_{2}$ merupakan oksidator kuat yang menghasilkan radikal hidroksil melalui dekomposisi $\mathrm{H}_{2} \mathrm{O}_{2}$. Pada saat $\mathrm{H}_{2} \mathrm{O}_{2}$ ditambahkan ke sistem US, maka getaran dari gelombang ultrasonik akan merangsang pembentukan radikal hidroksil. Meningkatnya jumlah $\mathrm{H}_{2} \mathrm{O}_{2}$ yang bereaksi akan meningkatkan jumlah $\mathrm{H}_{2} \mathrm{O}_{2}$ yang berdifusi dengan gelombunggelembung kavitasi, sehingga jumlah radikal hidroksil yang dihasilkan untuk mengoksidasi komponen organik dalam LCRS juga akan meningkat. Oleh karena itu, penentuan konsentrasi optimal $\mathrm{H}_{2} \mathrm{O}_{2}$ yang digunakan sangat penting karena $\mathrm{H}_{2} \mathrm{O}_{2}$ mempunyai kondisi keterbatasan untuk dapat mengoksidasi komponen organik. Jika jumlah $\mathrm{H}_{2} \mathrm{O}_{2}$ sedikit maka akan menghasilkan pengaruh yang kurang bagus, begitu juga sebaliknya jika terlalu banyak maka akan menimbulkan efek scavenging. Persamaan 3 dan 4 adalah reaksi yang dapat menjelaskan efek scavenging $\mathrm{H}_{2} \mathrm{O}_{2}$.

$\mathrm{H}_{2} \mathrm{O}_{2}+\mathrm{OH}^{*} \rightarrow \mathrm{H}_{2} \mathrm{O}+\mathrm{OOH}^{*}$

$\mathrm{OOH}^{*}+\mathrm{OH}^{*} \rightarrow \mathrm{H}_{2} \mathrm{O}+\mathrm{O}_{2}{ }^{*}$

(Anotai et al., 2011) menyebutkan bahwa konsentrasi $\mathrm{H}_{2} \mathrm{O}_{2}$ dan $\mathrm{pH}$ mempunyai pengaruh yang berlawanan terhadap degradasi COD. Konsentrasi $\mathrm{H}_{2} \mathrm{O}_{2}$ mempunyai pengaruh positif sedangkan $\mathrm{pH}$ mempunyai pengaruh negatif terhadap degradasi COD. Semakin meningkatnya konsentrasi $\mathrm{H}_{2} \mathrm{O}_{2}$ akan memberikan efek positif terhadap degradasi COD. Degradasi COD akan meningkat dengan meningkatnya konsentrasi $\mathrm{H}_{2} \mathrm{O}_{2}$. Meningkatnya $\mathrm{pH}(2-4)$ akan menurunkan efisiensi degradasi COD karena potensial oksidasi dari hidroksil radikal $\left(\mathrm{OH}^{*}\right)$.

Gambar 4 menunjukkan hubungan antara $\mathrm{pH}$ dan waktu reaksi terhadap persentase degradasi COD yang diilustrasikan dengan plot $Y$ sebagai persentase degradasi COD dan sumbu $X$ sebagai $\mathrm{pH}$ dan waktu reaksi dengan konsentrasi $\mathrm{H}_{2} \mathrm{O}_{2}$ tetap 300 ppm.

Dari plot tersebut dapat dilihat bahwa persentase penurunan COD LCRS meningkat pada kondisi $\mathrm{pH}$ terendah dan waktu reaksi tertinggi. Derajat keasaman suatu larutan memiliki pengaruh besar terhadap jalannya laju reaksi. Dalam proses degradasi limbah dengan menggunakan peroksida semakin kecil $\mathrm{pH}$ yang dimiliki oleh suatu limbah maka proses degradasi dengan menggunakan hidrogen peroksida akan semakin cepat (Petri et al., 2011).

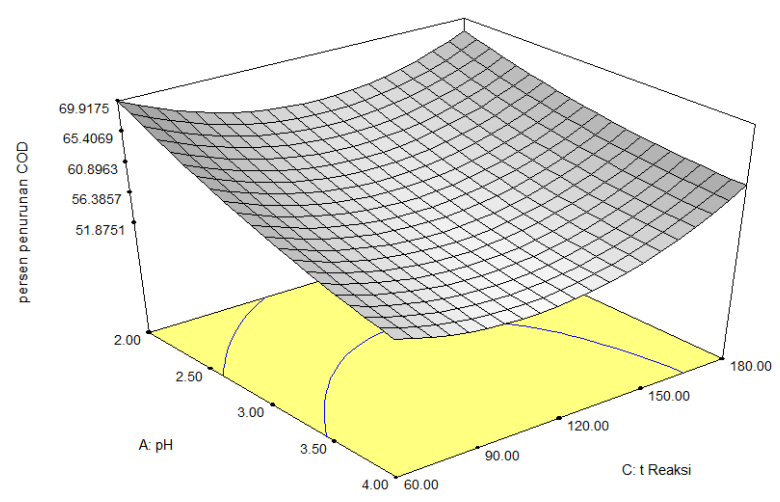

(a)

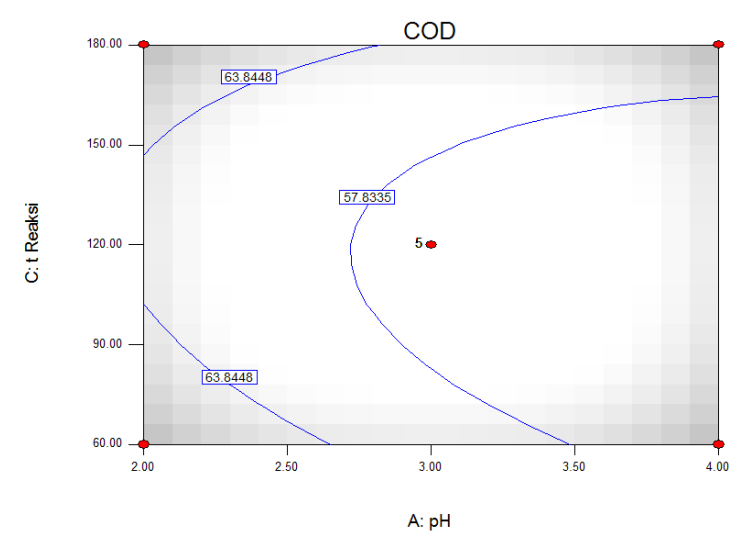

(b)

Sumber: Data yang diolah

Gambar 4. Pengaruh $\mathrm{pH}$ dan waktu reaksi terhadap \% penurunan COD secara sonochemical: (a) plot 3D (b) plot kontur (konsentrasi $\mathrm{H}_{2} \mathrm{O}_{2} 300 \mathrm{ppm}$ )

Hubungan antara konsentrasi $\mathrm{H}_{2} \mathrm{O}_{2}$ dan waktu reaksi terhadap persentase degradasi COD diilustrasikan pada Gambar 5, dimana plot $Y$ adalah persentase degradasi COD dan sumbu $X$ adalah konsentrasi $\mathrm{H}_{2} \mathrm{O}_{2}$ dan waktu reaksi dengan $\mathrm{pH}$ tetap (3). 


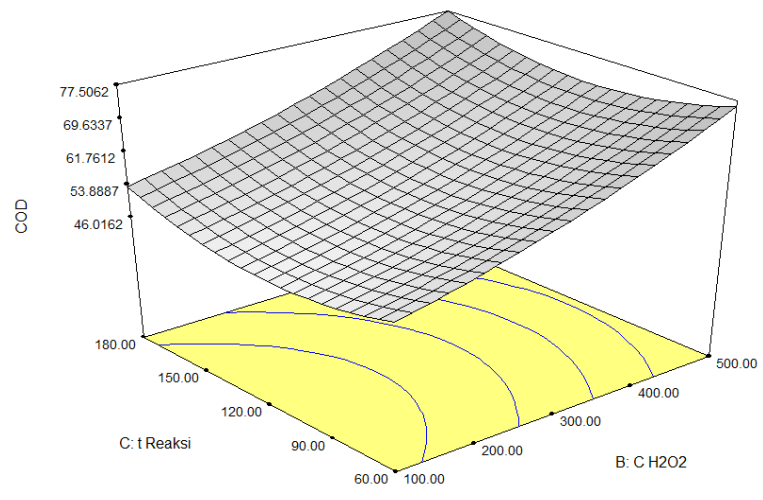

(a)

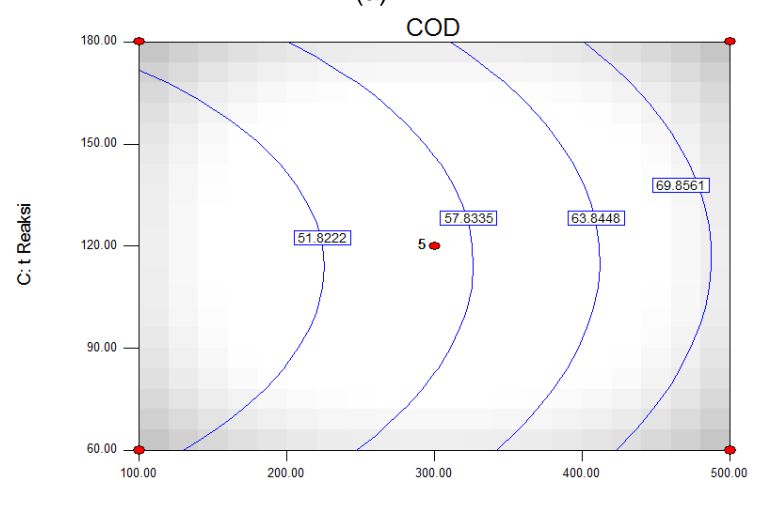

(b)

Sumber: Data yang diolah

Gambar 5. Pengaruh konsentrasi $\mathrm{H}_{2} \mathrm{O}_{2}$ dan waktu reaksi terhadap \% penurunan COD secara sonochemical: (a) plot 3D (b) plot kontur $(\mathrm{pH} 3)$

Dari plot tersebut dapat dilihat bahwa kondisi maksimum dari proses degradasi LCRS secara sonochemical diperoleh pada kondisi konsentrasi $\mathrm{H}_{2} \mathrm{O}_{2}$ dan waktu reaksi tertinggi. Banyaknya persen $C O D$ yang terdegradasi akan meningkat seiring dengan bertambahnya waktu hingga reaksi mencapai keadaan setimbang. Penelitian yang dilakukan oleh (Chu et al., 2011) menunjukkan bahwa persen degradasi COD meningkat seiring dengan bertambahnya waktu dan mencapai kesetimbangan pada waktu 2 jam.

(Torii et al., 2004), (Mahamuni and Adewuyi, 2010) dan (Sievers, 2011) menjelaskan pada saat berlangsungnya proses sonochemical, akan terjadi gelombang akustik di dalam LCRS yang disebabkan oleh adanya getaran dari gelombang ultrasonik. Gelombang akustik terjadi pada range gelombang ultrasonik $20 \mathrm{kHz}$ hingga $1 \mathrm{MHz}$. Getaran dari gelombang ultrasonik akan menghasilkan $\mathrm{OH}^{*}$ radikal yang akan mengoksidasi polutan-polutan pada LCRS sesuai dengan reaksi pada persamaan 5-8.

$\mathrm{H}_{2} \mathrm{O} \longrightarrow \mathrm{H}^{*}+\mathrm{OH}^{*}$

$\mathrm{H}^{*}+\mathrm{O}_{2} \longrightarrow \mathrm{HOO}^{*}$

$\mathrm{LCRS}+\mathrm{OH}^{*}$

Hasil degradasi.

$\mathrm{LCRS}+\mathrm{HOO}^{*} \longrightarrow$ Hasil degradasi.....(8)

(Tran et al., 2015) juga menjelaskan ketika sampel limbah cair diberikan getaran dari gelombang ultrasonik, maka akan menghasilkan gelombang akustik yang akan membentuk gelembunggelembung. Gelembung-gelembung tersebut akan hancur dan mengakibatkan naiknya temperatur dan tekanan yang sangat besar. Molekul-molekul gas air di gelembung-gelembung tersebut akan pecah dan membentuk $\mathrm{OH}^{*}$. $\mathrm{OH}^{*}$ inilah yang akan mengoksidasi dan menghilangkan berbagai jenis bahan pencemar organik pada LCRS.

\section{Optimasi \% Degradasi COD pada LCRS}

Hasil optimasi memberikan empat solusi proses sonochemical untuk menghasilkan prediksi respon optimal seperti ditunjukkan pada Tabel 5. Optimasi dilakukan untuk memperoleh kondisi optimum pada proses pengolahan LCRS secara sonochemical. Optimasi $\mathrm{pH}$, konsentrasi $\mathrm{H}_{2} \mathrm{O}_{2}$ dan waktu reaksi dilakukan dengan menggunakan metode response surface Box-Behnken. Variabel $\mathrm{pH}$, konsentrasi $\mathrm{H}_{2} \mathrm{O}_{2}$ dan waktu reaksi diatur sesuai dengan kisaran levelnya. Nilai persen penurunan kadar COD diatur pada nilai maksimum untuk memperoleh hasil terbaik.

Dari Tabel 5 dipilih kondisi optimasi pada yang diberikan pada solusi nomor satu, karena tingkat desirabilitasnya paling tinggi yaitu 0,983 dan persen penurunan COD juga tinggi. Prediksi kondisi optimum pada penelitian ini adalah $\mathrm{pH} 2$, konsentrasi $\mathrm{H}_{2} \mathrm{O}_{2} 500 \mathrm{ppm}$ dan waktu reaksi 119,98 menit, dengan nilai COD $81,88 \%$. Gambar plot 3D dan plot kontur desirabilitas untuk kondisi optimum pengolahan LCRS secara sonochemichal. ditampilkan pada Gambar 6. 


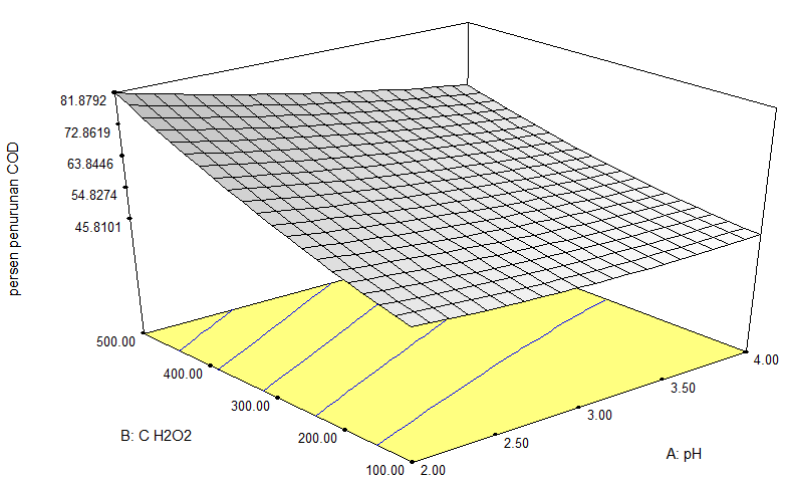

(a)

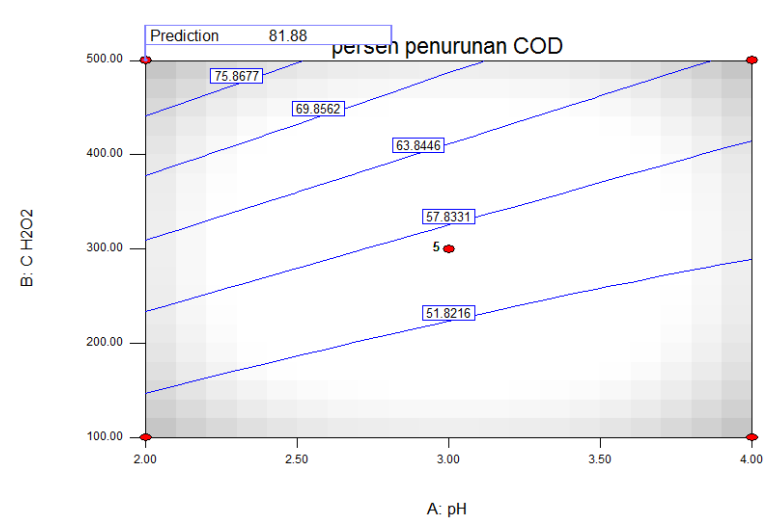

(b)

Sumber: Data yang diolah

Gambar 6. (a) Plot 3D dan (b) plot kontur kondisi optimum pengolahan LCRS secara sonochemichal.

Tabel 5. Solusi optimasi pengolahan LCRS secara sonochemical

\begin{tabular}{cccccc}
\hline No. & $\mathrm{pH}$ & $\mathrm{H}_{2} \mathrm{O}_{2}$ & Waktu reaksi & Penurunan COD & Desirability \\
\hline 1 & 2,00 & 500 & 119,98 & 81,8787 & 0,983 \\
2 & 2,04 & 500 & 120,00 & 81,3779 & 0,981 \\
3 & 2,40 & 498,40 & 81,38 & 79,7832 & 0,857 \\
4 & 2,52 & 499,95 & 70,60 & 80,16 & 0,814
\end{tabular}

Sumber: Data penelitian sendiri yang diolah

\section{KESIMPULAN}

Proses degradasi LCRS dengan menggunakan metode sonochemical sangat dipengaruhi oleh konsentrasi $\mathrm{H}_{2} \mathrm{O}_{2}$, $\mathrm{pH}$ larutan, dan waktu reaksi yang digunakan, semakin besar konsentrasi $\mathrm{H}_{2} \mathrm{O}_{2}$, semakin kecil $\mathrm{pH}$ dan semakin lama waktu yang digunakan maka degradasi COD dari limbah cair rumah sakit akan semakin besar. Kondisi optimum degradasi LCRS dengan menggunakan sonochemical diperoleh pada $\mathrm{pH}$ 2, konsentrasi $\mathrm{H}_{2} \mathrm{O}_{2} 500$ ppm, dan waktu reaksi 119,98 menit dengan persen penurunan COD sebesar 81,88\%. Berdasarkan disain Box-Behnken pada software DX 6.0.6 diketahui bahwa model yang sesuai digunakan pada proses degradasi LCRS dengan menggunakan metode sonochemical adalah model kuadratik. Nilai $R^{2}$ yang diperoleh adalah 0,9499 dan $A d j-R^{2}$ adalah 0,8856. Nilai $p$ value 0,0009 yang menunjukkan bahwa model ini sangat sesuai untuk digunakan.

\section{UCAPAN TERIMA KASIH}

Penulis mengucapkan terima kasih kepada Rumah Sakit Umum Zainoel Abidin
Kota Banda Aceh khususnya bagian IPSL yang telah memberikan izin pengambilan sampel untuk penelitian ini.

\section{DAFTAR PUSTAKA}

Abu, S., Hamidi, A., Aziz, A., Bashir, M., 2014. Application of Response Surface Methodology (RSM) for Optimization of Semi-Aerobic Landfill Leachate Treatment Using Ozone. Appl Water Sci 2014. doi:http://dx.doi.org/10.1007/s13201014-0156-z

Agarry SE, CN, O., RO, Y., 2012. Enhanced bioremediation of soil artificially contaminated with kerosene: Optimization of biostimulation agents through statistical experimental design. J. Pet. Environ. Biotechnol. 3, 1-8. doi:10.4172/2157-7463.1000120

Anotai, J., Singhadech, S., C., S.C., Lu M, C., 2011. Comparison of O-toluidine degradation by fenton, electro-fenton and photoelectro-fenton processes. J. Hazard. Mater. 395-401. 
Bagal, M. V., Gogate, P.R., 2014. Wastewater treatment using hybrid treatment schemes based on cavitation and fenton chemistry: A review. Ultrason. Sonochem. 21, 114. doi:10.1016/j.ultsonch.2013. 07.009

Chu, L., Wang, J., Dong, J., Liu, H., Sun, $X ., 2011$. Treatment of coking wastewater by an advanced fenton oxidation process using iron powder and hydrogen peroxide. Chemosphere $x x x$, 1-6. doi:10.1016/j.chemosphere.2011.09.0 07

Garcia, G., Sáez, V., Tudela, I., DíezGarcia, M.I., Deseada Esclapez, M., Louisnard, O., 2010. Sonochemical treatment of water polluted by chlorinated organocompounds. A review. Water 2, 28-74. doi:10.3390/w2010028

Liu, Z., Dang, J., Wang, Q., Yu, M., Jiang, L., Mei, L., Shao, Y., Tao, Y., 2013. Optimization of polysaccharides from lycium ruthenicum fruit using rsm and its anti-oxidant activity. Int. J. Biol. Macromol. 61, 127-134. doi:10.1016/ j.jjbiomac.2013.06.042

Mahamuni, N.N., Adewuyi, Y.G., 2010. Advanced oxidation processes (aops) involving ultrasound for waste water treatment:A review with emphasis on cost estimation. Ultrason. Sonochem. 17, 990-1003. doi:10.1016/j.ultsonch. 2009.09.005

Manohar, M., Joseph, J., Selvaraj, T., Sivakumar, D., 2013. Application of box Behnken design to optimize the parameters for turning inconel 718 using coated carbide tools. Int. J. Sci. Eng. Res. 4, 620-642. doi:10.4314/ tjpr.v11i5.2

Mantzavinos, D., Poulios, I., FernándezIbañez, P., Malato, S., 2014. Advanced Oxidation Processes for Environmental Protection. Environ. Sci. Pollut. Res. 21, 12109-12111. doi:10.1007/s11356-014-3359-9
Neppolian, B., Ashokkumar, M., Tudela, I., Gonz, J., 2012. Advances in water treatment and pollution prevention. doi:10.1007/978-94-007-4204-8

Patil, P.N., Bote, S.D., Gogate, P.R., 2014. Degradation of imidacloprid using combined advanced oxidation processes based on hydrodynamic cavitation. Ultrason. Sonochem. 21, 1770-1777. doi:10.1016/j.ultsonch. 2014.02.024

Petri, B.G., Watts, R.J., Teel, A.L., Huling, S.G., Brown, R.A., 2011. In situ chemical oxidation for groundwater remediation. doi:10.1007/978-1-44197826-4

Philippi, K., Tsamandouras, N., Grigorakis, S., Makris, D.P., 2016. Ultrasoundassisted green extraction of eggplant peel (Solanum melongena) ppolyphenols using aqueous mixtures of glycerol and ethanol: Optimisation and kinetics. Environ. Process. 3, 369-386. doi:10.1007/s40710-0160140-8

Qiu, P., Cui, M., Kang, K., Park, B., Son, Y., Khim, E., Jang, M., Khim, J., 2014. Application of Box-Behnken design with response surface methodology for modeling and optimizing ultrasonic oxidation of arsenite with $\mathrm{H} 2 \mathrm{O} 2$. Cent. Eur. J. Chem. 12, 164-172. doi:10.2478/s11532-013-0360-y

Sievers, M., 2011. Advanced oxidation processes, Cutec -Institute $\mathrm{GmbH}$, Clausthal-Zellerfeld, Germany.

Torii, T., Yasui, K., Yasuda, K., lida, Y., Tuziuti, T., Suzuki, T., Nakamura, M., 2004. Generation and consumption rates of $\mathrm{OH}$ radicals in sonochemical reactions. Res. Chem. Intermed. 30, 713-721. doi:10.1163/156856704185 6918

Tran, N., Drogui, P., Brar, S.K., 2015. Sonochemical techniques to degrade pharmaceutical organic pollutants. Environ. Chem. Lett. 13, 251-268. doi:10.1007/s10311-015-0512-8 